University of Nebraska - Lincoln

DigitalCommons@University of Nebraska - Lincoln

Faculty Publications from the Harold W. Manter Laboratory of Parasitology

\title{
8-1989
}

\section{Phylogenetic Relationships among Genera of the Tetrabothriidae (Eucestoda)}

\author{
Eric P. Hoberg \\ United States Department of Agriculture, eric.hoberg@ars.usda.gov
}

Follow this and additional works at: https://digitalcommons.unl.edu/parasitologyfacpubs

Part of the Parasitology Commons

Hoberg, Eric P., "Phylogenetic Relationships among Genera of the Tetrabothriidae (Eucestoda)" (1989). Faculty Publications from the Harold W. Manter Laboratory of Parasitology. 312.

https://digitalcommons.unl.edu/parasitologyfacpubs/312

This Article is brought to you for free and open access by the Parasitology, Harold W. Manter Laboratory of at DigitalCommons@University of Nebraska - Lincoln. It has been accepted for inclusion in Faculty Publications from the Harold W. Manter Laboratory of Parasitology by an authorized administrator of DigitalCommons@University of Nebraska - Lincoln. 


\title{
PHYLOGENETIC RELATIONSHIPS AMONG GENERA OF THE TETRABOTHRIIDAE (EUCESTODA)*
}

\author{
Eric P. Hoberg \\ Department of Pathology and Microbiology, Atlantic Veterinary College, University of Prince Edward Island, \\ 550 University Avenue, Charlottetown, Prince Edward Island, Canada C1A 4P3
}

ABSTRACT: Cladistic analysis of the generic-level relationships within the family Tetrabothriidae was conducted. A single cladogram resulted from evaluation of 28 homologous transformation series representing 41 character states. The genus Tetrabothrius was recognized as plesiomorphic followed by Chaetophallus and Trigonocotyle. The latter was considered as the sister group for the remaining tetrabothriid genera of marine mammals. Anophryocephalus, Strobilocephalus, and Priapocephalus are among the most highly derived genera and are postulated as having close evolutionary affinities. Comparisons to previous explicit hypotheses for relationships among the genera indicated the present analysis was the most efficient phylogenetic statement (consistency index $=85.4 \%$ ) for the 28 attributes evaluated. The recognition of Tetrabothrius as primitive and a natural grouping of Anophryocephalus, Strobilocephalus, and Priapocephalus in part confirmed results of previous studies of the Tetrabothriidae.

Tetrabothriidae Linton, 1891, constitutes a prominent group of cestodes among marine mammals and seabirds predominantly in pelagic ecosystems (Baer, 1954; Temirova and Skrjabin, 1978). Six genera are currently recognized: Tetrabothrius Rudolphi, 1819 (approximately 50 species among Procellariiformes, Sphenisciformes, Pelecaniformes, Charadriiformes, and Gaviiformes; and 8 species among Cetacea), Chaetophallus Nybelin, 1916 (2 species among Procellariiformes), Strobilocephalus Baer, 1932 (monotypic among Cetacea), Priapocephalus $\mathrm{Ny}$ belin, 1922 (3 species in Cetacea), Trigonocotyle Baer, 1932 (3 species in Cetacea), and Anophryocephalus Baylis, 1922 (3 species in Pinnipedia) (Temirova and Skrjabin, 1978; Schmidt, 1986). The tetrabothriids have been classified among the Pseudophyllidea (Nybelin, 1922), Cyclophyllidea (Fuhrmann, 1932; Wardle and McLeod, 1952; Schmidt, 1986; and others), as a suborder of the Tetraphyllidea (Spasskii, 1958; Temirova and Skrjabin, 1978) or in the separate order Tetrabothridea (Baer, 1954).

A tetraphyllidean relationship for the tetrabothriids had been considered previously by Baylis (1926) and later by Baer (1954). However, Baer's hypothesis suggested that tetrabothriids were a lineage of the Proteocephalidea that diverged as the sister group for all Tetraphyllidea. Alternative hypotheses for the origin of the tetrabothriids from tetraphyllideans were presented

Received 24 March 1989; accepted 19 April 1989.

* Paper from Stunkard Centenary Session of the 1989 annual meeting of the American Society of Parasitologists. independently by Hoberg (1987a) and Galkin (1987) (see Spasskii, 1958; Temirova and Skrjabin, 1978). Studies of the structure and ontogeny of larval Tetrabothrius spp. supported a sister group relationship between the Tetrabothriidae and some derived tetraphyllideans (Hoberg, 1987a). Development of the metacestodes of Tetrabothrius and Anophryocephalus appears to share a homologous pattern with Acanthobothrium Beneden, 1849. Additionally, the holdfasts of many Tetrabothrius spp. (see Baer, 1954) appear most similar to those characteristics of $\mathrm{Cer}$ atobothrium Monticelli, 1892 (Oncobothriidae), or Monorygma Diesing, 1863, and Dinobothrium Beneden, 1889 (Phyllobothriidae) (Baylis, 1926; Williams, 1968; Hoberg, 1987a). These observations formed the basis for recognizing some of these tetraphyllideans as the putative sister group of the tetrabothriiids.

Attempts to identify the original homeothermic hosts of the tetrabothriids (e.g., seabirds or marine mammals) have been equivocal. Baer (1932) suggested that pinnipeds were the primary hosts with subsequent colonization occurring independently among cetaceans and marine birds. Baer (1954) later recognized seabirds as primitive hosts, using host specificity as an indicator of relationship among genera and species, and considered that host-switching had occurred secondarily among marine mammals. Galkin (1987) attempted to refute the latter hypothesis for origin and diversification of the tetrabothriids, suggesting that marine mammals, particularly cetaceans, were the initial hosts. Hoberg (1987a) indicated that data were currently insufficient to corroborate any definite pattern of evolutionary 
relationships for hosts and parasites within the family, but he considered the probability that avian hosts were plesiomorphic.

Although the family has received attention in 2 monographs (Baer, 1954; Temirova and Skrjabin, 1978) the taxonomy and relationships among the genera and particularly for species referred to Tetrabothrius have remained confused. The validity of the 4 subgenera (Tetrabothrius, Oriana, Neotetrabothrius, and Culmenamniculus) suggested on morphological grounds by Baer (1954) and subsequently named by Murav'eva (1975) has not been well established (see Odening, 1982). Inadequate descriptions of the genital atrium and other characteristics in many species may not allow their reliable placement at the subgeneric level. Recent studies of Tetrabothrius spp. (Hoberg, 1987b) have indicated the necessity to reevaluate the status of many species because of incomplete documentation of intraspecific variation of major diagnostic characters (structure of genital atrium, length of male canal, number of testes) and because of the apparent lack of consistency in other morphological attributes. Among other genera, there has been considerable disagreement (Baer, 1932, 1954; Temirova and Skrjabin, 1978; Galkin, 1987) over the evolutionary affinities of Anophryocephalus, Strobilocephalus, and Priapocephalus.

As the basis for broader studies among the Tetrabothriidae, preliminary phylogenetic hypotheses, presented herein, were developed for generic-level relationships within the family. Completion of analyses among the genera (and later species) will promote the development of a natural classification for the group and provide a means of assessing earlier evaluations of evolutionary relationships (e.g., Baer, 1932, 1954).

\section{MATERIALS AND METHODS}

Relationships of 6 genera of Tetrabothriidae were analyzed using cladistics or phylogenetic systematics (Hennig, 1966; Wiley, 1981). The PAUP computer systematics program (Version 2.4), based on parsimony criteria, was used to construct phylogenetic hypotheses (Swofford, 1985). The small number of genera in the study group allowed analyses to be conducted with the ALLTREES option; trees were rooted with a designated ancestor and Farris optimization was employed (Swofford, 1985).

\section{Specimens examined}

Specimens of several Tetrabothrius spp. from avian hosts and representatives of all genera of tetrabothriids (except Chaetophallus) were examined. Material was borrowed from the U.S. National Museum (USNM), the British Museum of Natural History (BMNH) and from the collections of R. L. Rausch (RLR), and additional specimens are maintained in the author's collections (EPH). Specimens included: Tetrabothrius shinni Hoberg, 1987 (USNM 79657), T. jagerskioldi Nybelin, 1916, T. cylindraceus Rudolphi, 1819, T. laccocephalus Spätlich, 1909, and T. erostris Loennberg, 1896 (all EPH); Trigonocotyle prudhoei Markowski, 1955 (BMNH 1956.5.16.65-71, excluding material from Lagenorhynchus australis [Peale] and Steno bredanensis [Lesson]), T. globicephalae Baer, 1954 (BMNH 1956.5.16.63-64), T. monticelli (Linton, 1923) (USNM $8418=T$. globicephalae) and Trigonocotyle sp. (USNM 77368, 77679); Strobilocephalus triangularis (Diesing, 1850) (USNM 74662); Priapocephalus cf. eschrichtii Murav'eva and Treshchev, 1970 (RLR 31882); and Anophryocephalus anophrys Baylis, 1922 (BMNH 1922.5.3.1-6); A. ochotensis Deliamure and Krotov, 1955 (USNM 76200; RLR 7659), and $A$. skrjabini (Krotov and Deliamure, 1955) (USNM 75942, 75960, 76188 , and 76178 , all previously referred to $A$. ochotensis).

\section{Character analysis}

Homologous characters used in the analysis were derived primarily from the study of material representing tetrabothriids. Reference to detailed descriptions and redescriptions of tetrabothriids from marine mammals (Rees, 1956; Skrjabin and Murav'eva, 1972, 1978) and seabirds (Spätlich, 1909; Nybelin, 1916; Rawson, 1964; Burt, 1976, 1978; Andersen and Lysfjord, 1982), along with monographs on the Tetrabothriidae (Baer, 1932, 1954; Temirova and Skrjabin, 1978) and treatments of other cestodes (Linton, 1922; Fuhrmann, 1932; Wardle and McLeod, 1952; Williams, 1968; Schmidt, 1986) augmented the study. Polarization of character states was accomplished by outgroup comparison (Lundberg, 1972; Wiley, 1981). Primary outgroups were tetraphyllideans of the genera Phyllobothrium Beneden, 1849, Dinobothrium, Monorygma, and Ceratobothrium. These taxa were selected based on recognition of some derived Tetraphyllidea as the putative sister group for the Tetrabothriidae (see Spasskii, 1958; Hoberg, 1987a; Galkin, 1987).

Polarity of 3 characters (genital atrium [2]; male canal [3]; position of ovary $[7,8]$ ) was reevaluated with reference to the functional outgroup (Tetrabothrius) following preliminary analyses (see Watrous and Wheeler, 1981). Four characters were split into independent transformation series to account for derivation of some character states (position of ovary [7, $8]$; position of testes [10, 11]; shape of scolex [21, 22]; and structure of auricular appendages [27, 28]) (see Glen and Brooks, 1985; Hoberg, 1986). A summary of the 28 homologous series, representing 41 character states, is presented below and in a numerical matrix (Table I). Plesiomorphic states are coded as 0 , apomorphic as 1,2 , or 3 . In genera containing species exhibiting both primitive and derived states, specific characters were coded as plesiomorphic.

An integral part of the analysis included calculation of the consistency index (CI), a measure of the fit of specific characters to the hypothetical phylogeny (Farris, 1970). Values for CI were calculated for individual characters and for overall relationships within the family. Additionally, the CI was used as a basis of com- 
parison of the present analysis with previous explicit phylogenies (Baer, 1932, 1954) via the TOPOLOGY function of PAUP (Swofford, 1985).

\section{RESULTS}

\section{Characters}

1) Genital pore (position). Two states: $0=$ lateral; 1 = ventrolateral.

2) Genital atrium (structure). Among tetraphyllideans the genital atrium is unmodified, whereas, among all tetrabothriids, except Priapocephalus, it is complex. Coding of this character was accomplished by functional outgroup (Tetrabothrius) following preliminary analysis. Three states: $0=$ with extensive muscular modification; $1=$ dorsal component of atrium reduced, ventral aspect with deep muscular concavity; $2=$ atrium weakly developed, with vestigial ventral concavity.

3) Male canal. A character unique to the Tetrabothriidae (Baer, 1954), except Priapocephalus, also coded by functional outgroup. Two states: $0=$ present; 1 = absent.

4) Cirrus sac (shape). Two states: $0=$ cylindrical; $1=$ ovoid.

5) Uterine pore. Two states: $0=$ multiple; 1 $=$ single.

6) Uterus (extent). When completely gravid, the sacculate uterus may extend beyond the osmoregulatory canals. Two states: $0=$ beyond canals; $1=$ within canals

$7,8)$ Ovary (position). Split into 2 transformation series (see Glen and Brooks, 1985; Hoberg, 1986) and coded with reference to the functional outgroup, the ovary may be in the anterior $(0,0)$, equatorial $(0,1)$, or posterior $(1,0)$ region of the proglottid. Character 7. Two states: $0=$ anterior; $1=$ posterior. Character 8 . Two states: $0=$ anterior; $1=$ equatorial.

9) Testes (number). Two states: $0=$ testes $>$ $100 ; 1=$ few testes.

10, 11) Testes (position). Split into separate transformation series, the testes may surround the ovary $(0,0)$, be postovarian $(1,0)$ or lateral to the ovary $(0,1)$. Character 10 . Two states: 0 = surround; $1=$ postovarian. Character 11 . Two states: $0=$ surround; 1 = lateral.

12) Testes (position). Two states: $0=$ contained within osmoregulatory canals; $1=$ extending beyond canals.

13) Testes (position). Two states: $0=$ dorsal; $1=$ dorsal and ventral fields.

14) Vitelline gland (form). Two states: $0=$ follicular; 1 = compact.

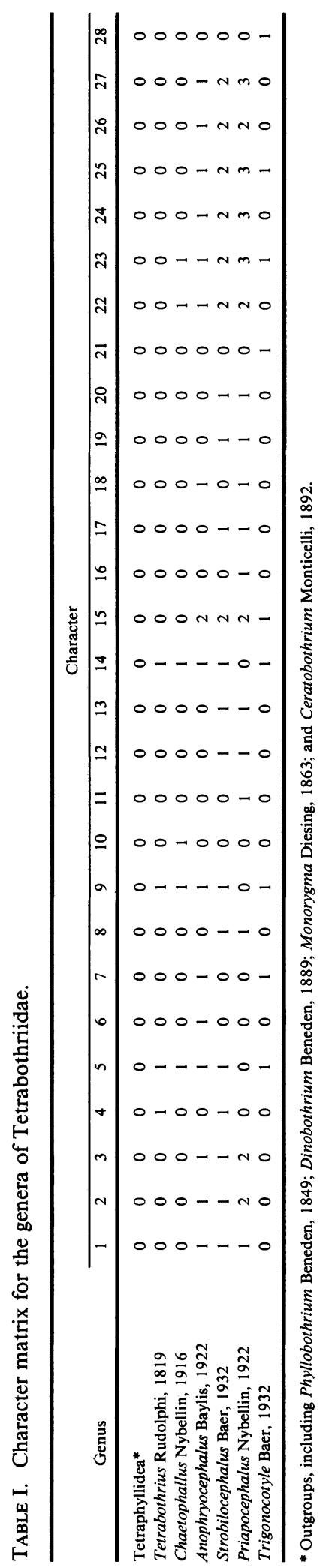


TABLE II. Consistency indices of characters used in the analysis of the Tetrabothriidae.

\begin{tabular}{|c|c|c|}
\hline $\begin{array}{c}\text { Character } \\
\text { number }\end{array}$ & Character & $\mathrm{CI}$ \\
\hline 1 & Genital pore-position & 1.0 \\
\hline 2 & Genital atrium - structure & 1.0 \\
\hline 3 & Male canal & 1.0 \\
\hline 4 & Cirrus sac-shape & 0.50 \\
\hline 5 & Uterine pore & 0.50 \\
\hline 6 & Uterus-extent & 1.0 \\
\hline 7 & Ovary-position & 0.50 \\
\hline 8 & Ovary-position & 1.0 \\
\hline 9 & Testes-number & 0.50 \\
\hline 10 & Testes-position & 1.0 \\
\hline 11 & Testes-position & 1.0 \\
\hline 12 & Testes-position & 1.0 \\
\hline 13 & Testes-position & 1.0 \\
\hline 14 & Vitelline gland-form & 0.50 \\
\hline 15 & Neck-length & 1.0 \\
\hline 16 & Genital ducts-position & 1.0 \\
\hline 17 & Genital ducts-position & 1.0 \\
\hline 18 & Osmoregulatory canals - dorsal & 0.50 \\
\hline 19 & Scolex-osmoregulatory canals & 1.0 \\
\hline 20 & Scolex-embedded & 1.0 \\
\hline 21 & Scolex-shape & 1.0 \\
\hline 22 & Scolex-shape & 0.667 \\
\hline 23 & Bothridia-shape & 1.0 \\
\hline 24 & Bothridia-depth & 1.0 \\
\hline 25 & Bothridia-muscularization & 1.0 \\
\hline 26 & Apical development & 1.0 \\
\hline 27 & Auricles-structure & 1.0 \\
\hline 28 & Auricles-structure & 1.0 \\
\hline
\end{tabular}

15) Neck (length). Two states: $0=$ short; $1=$ long.

16) Genital ducts (position). Two states: $0=$ between osmoregulatory canals; $1=$ ventral to canals.

17) Genital ducts (position). Two states: $0=$ median; $1=$ ventral.

18) Osmoregulatory system (dorsal canals). Two states: 0 = fully developed; $1=$ atrophied.

19) Scolex (osmoregulatory canals). Two states: $0=$ simple, tubular; $1=$ subtegumental and reticulate.

20) Scolex (position in host). Two states: $0=$ superficial contact with intestinal mucosa; $1=$ embedded in mucosa.

$21,22)$ Scolex (shape). Split into separate transformation series, the scolex may be rectangular and flat $(0,0)$, rectangular and cuboidal $(1,0)$, round and flat $(0,1)$ or globular $(0,2)$. Character 21. Two states: $0=$ rectangular and flat; $1=$ rectangular and cuboidal. Character 22 . Three states: $0=$ rectangular and flat; $1=$ round and flat; $2=$ globular.

23) Bothridia (shape). Four states: $0=$ rectangular; 1 = round; $2=$ triangular; $3=$ absent.

24) Bothridia (depth). Four states: $0=$ shallow; 1 = intermediate; $2=$ deep; $3=$ absent.
25) Bothridia (muscularization). Four states: $0=$ slight $; 1=$ moderate; $2=$ great; $3=$ absent.

26) Apical development (excluding auricular appendages). Three states: $0=$ slight; $1=$ moderate; 2 = great.

$27,28)$ Auricular structures. A complex character split into independent transformation series. In the genera Tetrabothrius and Chaetophallus, as in Dinobothrium, there is a single auricle fused to an anteromedial extension on each bothridium $(0,0)$ (see Spätlich, 1909; Linton, 1922; Baylis, 1926; Rees, 1956; Andersen and Lysfjord, 1982). In all species of Anophryocephalus, there are a pair of auricular structures, generally not fused, directed laterally and medially on the anterior margin of each bothridium $(1,0)$ (Baer, 1954; Murav'eva and Popov, 1976). In Strobilocephalus, there is a single auricle directed laterally from each bothridium $(2,0)$ (Baer, 1954). Trigonocotyle is characterized by 3 independent auricular appendages on the margins of the bothridia $(0,1)$ (Baer, 1932, 1954; Temirova and Skrjabin, 1978), whereas auricles are absent in Priapocephalus $(3,0)$. Character 27. Four states: as in Tetrabothrius (0); as in Anophryocephalus (1); as in Strobilocephalus (2); as in Priapocephalus (3). Character 28. Two states: similar to Tetrabothrius (0); as in Trigonocotyle (1).

\section{Phylogeny of the Tetrabothriidae}

A single cladogram for the 6 genera of Tetrabothriidae resulted from an analysis of 28 homologous series representing 41 character states (Fig. 1). This phylogenetic hypothesis was strongly supported with a $\mathrm{CI}$ of $85.4 \%$ (minimum length $=41$; required changes $=48$ ), indicating a good fit of these data to the cladogram. Consistency values for individual characters are presented in Table II. Homoplasy was postulated for parallel development in 1 character (ovoid cirrus sac in Tetrabothrius and Strobilocephalus) and evolutionary reversals of 6 additional attributes (uterine pore, position of ovary, number of testes, form of vitelline gland, dorsal osmoregulatory canals, and shape of scolex). These latter instances of homoplasy were largely associated with Anophryocephalus, Strobilocephalus, and Priapocephalus.

Monophyly for the Tetrabothriidae is strongly supported by a synapomorphy for the anteroventral position of the vitelline gland (a consistent character excluded from the present analysis). Additional characters including the dorsal uterine pore (5) and compact form of the vitelline 


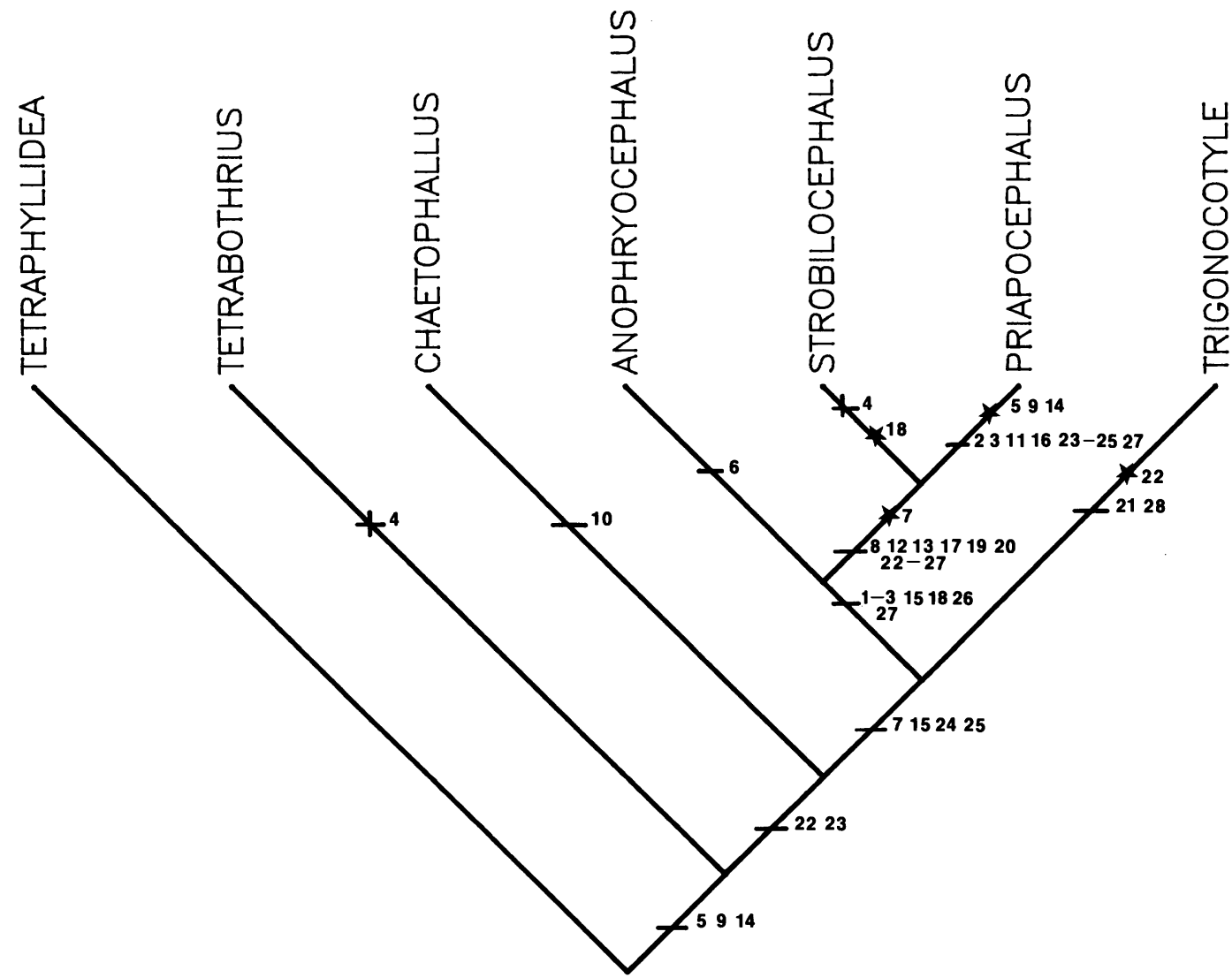

FIGURE 1. Cladogram for generic level relationships of the Tetrabothriidae. Apomorphic characters have been mapped on and designated by slashes; postulated evolutionary reversals and parallel development are indicated by stars and crosses, respectively. This hypothesis has a $\mathrm{CI}=85.4 \%$ representing a minimum of 41 steps and 48 postulated changes.

gland (14) are constant within the group but have postulated evolutionary reversals associated with Priapocephalus.

The genera Tetrabothrius and Chaetophallus are postulated as relatively plesiomorphic with respect to Anophryocephalus, Strobilocephalus, and Priapocephalus (Fig. 1). The inclusive grouping of these latter genera results from the ventrolateral position of the genital pore (1), relatively long neck (15), and an atrophied dorsal osmoregulatory system (18). A sister group relationship for Strobilocephalus and Priapocephalus is based on 7 synapomorphies, particularly the extent of the testes beyond the osmoregulatory canals (12), ventral aspect of the genital ducts (17), and the reticulate structure of the osmoregulatory canals in the scolex (19).

Additional foundation for the derived relationship of Priapocephalus resulted from a subsidiary analysis in which all characters of the scolex and genital atrium $(19-28 ; 2,3)$ were de- leted. Three cladograms of equal length $(\mathrm{CI}=$ $77.8 \%$ ) were found. All differed slightly with respect to the topology of Tetrabothrius, Chaetophallus, and Trigonocotyle but not in the grouping or placement of the AnophryocephalusPriapocephalus clade. This corroborates the character transformation series for the scolex and supports the sister group association of Strobilocephalus and Priapocephalus.

\section{DISCUSSION}

\section{Character evolution}

Analyses presented herein provide a foundation for postulating several trends in character evolution among the Tetrabothriidae. A suite of characters associated with the scolex has been influenced by hypertrophy of the apical region with concomitant reduction in the complexity and eventual loss of the auricles (as exemplified by Priapocephalus). A parallel situation is apparent in the simplification of the structurally 
intricate genital atrium, which is most strongly developed among species of Tetrabothrius. Although these characters are of considerable diagnostic importance, their exclusion from the analysis does not substantially alter the topology of the cladogram (Fig. 1). Thus, robust support for this phylogenetic hypothesis is indicated and an Anophryocephalus-Priapocephalus clade appears to have a firm empirical basis.

Attributes of the scolex have figured prominently in attempts at explicit phylogenetic reconstruction for the tetrabothriids (Baer, 1932, 1954) or in discussions of generic evolution within the family (Baylis, 1926; Temirova and Skrjabin, 1978; Galkin, 1987; Hoberg, 1987a). Structural similarities of the scolex in Tetrabothrius spp. (4 auriculate bothridia) and some tetraphyllideans had been recognized previously (Baylis, 1926; Baer, 1954; Temirova and Skrjabin, 1978); however, the extent to which these attributes represented homologies was disputed (see Andersen and Lysfjord, 1982). Hoberg (1987a) provided independent ontogenetic data for Tetrabothrius that for the first time firmly corroborated hypotheses for scolex homology among tetrabothriids and tetraphyllideans. The presence of homologous auriculate appendages in Tetrabothrius, Trigonocotyle, and all species of Anophryocephalus, as reported herein and confirmed for Strobilocephalus triangularis (see Baer, 1954), establishes a basis for monophyly of these tetrabothriids.

In contrast to "typical tetrabothriids," Priapocephalus was characterized by an absence of auricular structures or vestigial bothridia (Baer, 1954; Temirova and Skrjabin, 1978). The amorphous, globular scolex characteristic of this genus, in conjunction with a number of plesiomorphic attributes (multiple uterine pores, follicular vitelline gland, elongate cirrus sac and apparent lack of a complex genital atrium) has contributed to the controversy about generic affinities of these cetacean parasites (Baer, 1932, 1954; Temirova and Skrjabin, 1978; Galkin, 1987). Baer (1932) considered Priapocephalus to be highly derived and close to Strobilocephalus, but he later (1954) suggested independent origins for both genera from advanced Tetrabothrius spp. among cetaceans. Temirova and Skrjabin (1978) considered Priapocephalus and Tetrabothrius as sister groups sharing a common ancestor (prototetrabothriid with tetraphyllidean affinities) while also suggesting that among representatives of the former, the scolex was highly modified.
Following detailed study of scoleces from immature specimens of Priapocephalus, Temirova and Skrjabin (1978) concluded that the globular holdfast actually represented a "pseudoscolex" that was derived secondarily from the anterior proglottids during early development in the definitive host (see Baer, 1954). Their contention was based on the structure of the parenchyma, presence of longitudinal musculature, and osmoregulatory canals. Thus, it was considered that the "true scolex" was lost during the initial stages of development and that the pseudoscolex was not structurally or ontogenetically homologous to holdfasts characteristic of other tetrabothriids. There was also a suggestion of paedomorphosis (postdisplacement; see Fink, 1982) in the ontogeny of the pseudoscolex as development was thought to be preceded by penetration of the intestinal mucosa of the definitive host by metacestodes.

Observations of Priapocephalus and Strobilocephalus during the present study appear to refute contentions by Baer (1954) and Temirova and Skrjabin (1978) concerning structure of the scolex. In both genera, there is a globular holdfast with extensive development of longitudinal musculature. Additionally, the osmoregulatory canals comprise a highly reticulate anastomosing system of tubules that are subtegumental in location. These attributes, in addition to other recognized synapomorphies linking Strobilocephalus and Priapocephalus (Fig. 1), support the placement of the latter genus and structural homology of the holdfast. However, the potential for paedomorphic development of the scolex in Priapocephalus is of considerable interest. Such a pattern would parallel that known (Hoberg, 1987a) for Tetrabothrius and Anophryocephalus, suggesting a degree of uniformity in morphogenesis of the adult holdfast within the family Tetrabothriidae. This heterochronic sequence in ontogeny of the scolex is thought to be unique among the Eucestoda (Hoberg, 1987a).

\section{Comparison of phylogenies}

Baer $(1932,1954)$ presented the only explicit phylogenies for genera of the Tetrabothriidae, whereas Rees (1956), Temirova and Skrjabin (1978), Galkin (1987), and Hoberg (1987a) discussed some potential relationships among the genera. The evolutionary trees developed by Baer were redrawn (Figs. 2, 3) to allow direct comparison with the present phylogeny via the TOPOLOGY function of PAUP (Swofford, 1985). 


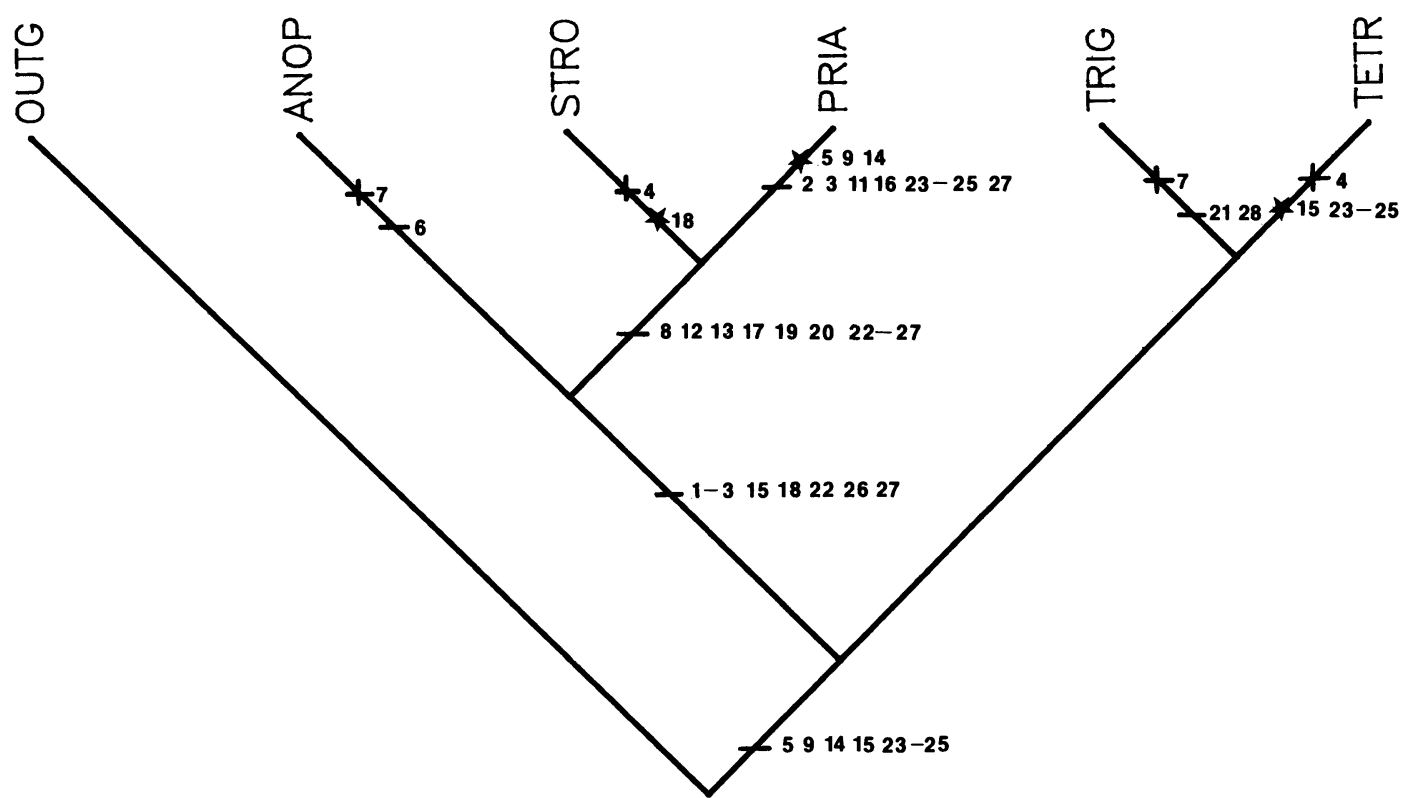

FIGURE 2. Cladogram prepared from phylogeny by Baer (1932) with character evolution evaluated by TOPOLOGY function. Characters are those in Figure 1; CI $=80 \%$ representing a minimum of 40 steps and 50 postulated changes (Chaetophallus deleted from analysis). Branch labels: OUTG, outgroup; ANOP, Anophryocephalus; STRO, Strobilocephalus; PRIA, Priapocephalus; TRIG, Trigonocotyle; TETR, Tetrabothrius.

Characters were mapped onto these alternative trees and optimized by Farris optimization (Farris, 1970) to allow a determination of the efficiency of the competing hypotheses (see Brooks et al., 1985a).

Baer (1932) recognized 2 lines of evolution from Anophryocephalus. Based on the assumption that auricular appendages were absent in Anophryocephalus, progressive development of the apical region led to the derivation of Strobilocephalus and Priapocephalus (Fig. 2). In contrast, modification of the apical region with development of auricular appendages occurred in Trigonocotyle and Tetrabothrius (here including Chaetophallus with Tetrabothrius). Although the grouping of Anophryocephalus, Strobilocephalus and Priapocephalus is supported, Baer's (1932) hypothesis is less efficient $(\mathrm{CI}=80 \%$, length $=$ 50 steps; versus $87 \%$ for the present cladogram with Chaetophallus deleted). Evolutionary reversals are postulated for 8 characters $(5,9,14$, $15,18,23,24,25)$ and parallel development for 2 attributes $(4,7)$.

The more detailed phylogeny postulated by Baer (1954) was considerably less parsimonious (CI $=57.7 \%$; length $=71$ steps $)$ with parallel derivation (characters $4,7,8,12,13,17,18,19$, $20,22,26)$ and evolutionary reversals $(1,2,3$, $5,9,14,15,22,23,24,25,26,27)$ of 11 and 13 characters, respectively. Figure 3 was drawn to recognize Baer's (1954) contention that avian tetrabothriids were primitive and that 2 advanced lineages were apparent among genera in mammalian hosts. Consequently, Chaetophallus, with the "classical type scolex," represents species of Tetrabothrius that Baer (1954) considered to be among the most primitive of those occurring among avian hosts (Procellariiformes). Extensive radiation of Tetrabothrius spp. occurred among seabirds but was apparently accompanied by minimal morphological diversification of the scolex (Baer, 1954). In contrast, species of Tetrabothrius among marine mammals were thought to be derived from those among seabirds with subsequent evolution involving trends in the reduction of the bothridia and atrophy of the apical region (Baer, 1954; Rees, 1956). Thus, Trigonocotyle was considered as originating independently from this latter group of Tetrabothrius spp. with continued alteration of the auricles and atrophy of the apical zone. However, hypertrophy of the apical region was postulated for Anophryocephalus, Strobilocephalus and Priapocephalus, with the latter also being independently derived from Tetrabothrius spp. among cetaceans. These hypotheses for independent derivation, adaptation, and convergence account for the increased length of the tree, and 7 of 11 cases 


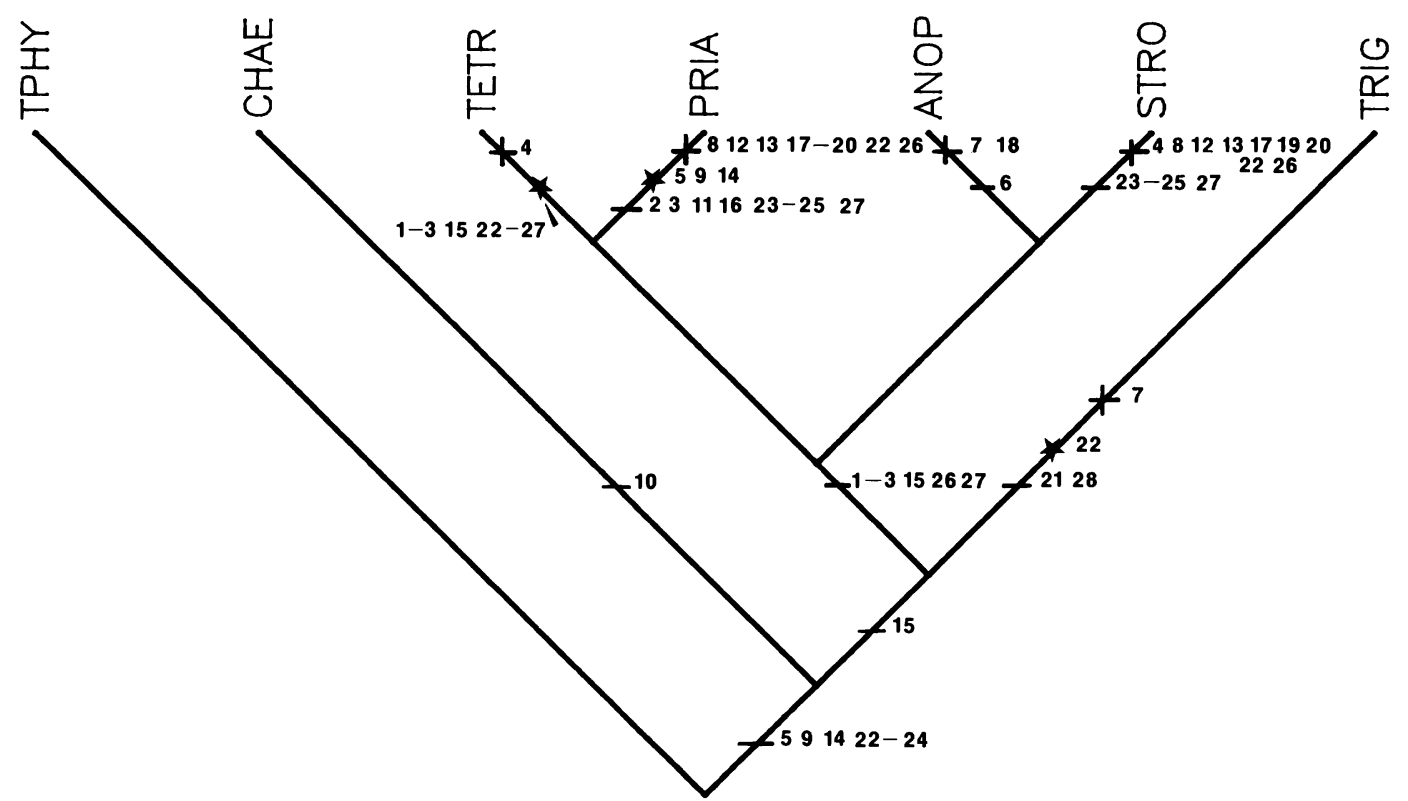

FIGURE 3. Cladogram prepared from phylogeny by Baer (1954), with character evolution evaluated by TOPOLOGY function. Characters are those in Figure $1 ; \mathrm{CI}=57.7 \%$ representing a minimum of 41 steps and 71 postulated changes. Branch labels as in Figure 2 except OUTG is replaced by TPHY, Tetraphyllidea.

of parallel evolution are postulated for Strobilocephalus and Priapocephalus.

Temirova and Skrjabin (1978) suggested that Tetrabothrius and Priapocephalus shared a common ancestor directly related to tetraphyllideans. Relationships of other genera were unresolved although they suggested that Anophryocephalus and Trigonocotyle were phylogenetically younger and derived from Tetrabothrius. Strobilocephalus was thought to be without definite association, an opinion refuted in the present study by synapomorphies associated with the genital atrium in the former genus and Anophryocephalus.

Galkin (1987) and Hoberg (1987a) considered Tetrabothrius as relatively primitive while suggesting a derived status for such genera as Anophryocephalus and Priapocephalus. Galkin (1987) in accordance with Baer $(1932,1954)$ and Rees (1956) suggested that Anophryocephalus represented the base of a lineage in which ensued progressive development of the apical region.

\section{Conclusions}

The present analysis constitutes a more efficient phylogenetic hypothesis for generic-level relationships within Tetrabothriidae than those provided in previous studies. Characters of the scolex and genital atrium have been the primary attributes considered in earlier evaluations (Baer, 1932, 1954; Rees, 1956; Temirova and Skrjabin, 1978). Although such were important in the current study, a suite of other homologous characters, not previously considered in evolutionary studies of the family, strongly supported the cladogram. In concordance with some previous studies, Tetrabothrius was postulated as relatively plesiomorphic (Baer, 1954; Rees, 1956; Temirova and Skrjabin, 1978; Galkin, 1987; Hoberg, 1987a) and the natural grouping of Anophryocephalus, Strobilocephalus, and Priapocephalus was reinforced (Baer, 1932; Hoberg, 1987a). Completion of phylogenetic analyses of genera and species of the Tetrabothriidae will provide for development of a natural classification for the group, an objective means of assessing previous phylogenetic hypotheses for relationships among species (e.g., Baer, 1954), and a basis of comparison to determine the degree of congruence between the phylogenetic histories of parasites and hosts as an indicator of parasitehost coevolution or colonization (see Brooks and Wiley, 1986; Brooks, 1988). The latter also may promote an evaluation of the role of parasite adaptive radiation in the evolution of this marine parasite fauna (see Brooks et al., 1985b; Hoberg, 1986, 1987a). 


\section{ACKNOWLEDGMENTS}

Specimens of some tetrabothriids were kindly loaned by Dr. R. H. Bray and Dr. D. I. Gibson of the British Museum (Natural History), Dr. J. R. Lichtenfels of U.S. National Museum, Dr. R. L. Rausch and Dr. A. Adams of the University of Washington, and Dr. M. D. Dailey of California State University, Long Beach. The study benefitted from discussions with Dr. D. R. Brooks, Dr. R. L. Rausch, and Dr. R. T. O'Grady. Preliminary analysis of some relationships among the tetrabothriids were conducted while the author was a Research Associate in the laboratory of Dr. G. L. Zimmerman at the College of Veterinary Medicine, Oregon State University.

\section{LITERATURE CITED}

ANDERSEN, K. I., AND S. LySFJord. 1982. The functional morphology of the scolex of two Tetrabothrius Rudolphi 1819 species (Cestoda; Tetrabothriidae) from penguins. Zeitschrift für Parasitenkunde 67: 299-307.

BAER, J. G. 1932. Contribution à l'étude des cestodes de cétacé. Revue Suisse de Zoologie 39: 195-228.

- 1954. Revision taxonomique et étude biologique des cestodes de la famille des Tetrabothriidae parasites d'oiseaux de haute mer et de mammiféres marins. Mémoires de L'Université de Neuchâtel Série Inquarto 1: 4-122.

BAYLIS, H. A. 1926. Some tetrabothriid cestodes from whales of the genus Balenoptera. Journal of the Linnean Society (London) 36: 161-172.

BRooKs, D. R. 1988. Macroevolutionary comparisons of host and parasite phylogenies. Annual Review of Ecology and Systematics 19: 235-259.

- R. T. O'Grady, AND D. R. GLen. 1985a. The phylogeny of the Cercomeria Brooks, 1982 (Platyhelminthes). Proceedings of the Helminthological Society of Washington 52: 1-20.

$\longrightarrow,-$, AND $\longrightarrow$ 1985b. Phylogenetic analysis of the Digenea (Platyhelminthes: Cercomeria) with comments on their adaptive radiation. Canadian Journal of Zoology 63: 41 1-443.

$\longrightarrow$, AND E. O. WILEY. 1986. Evolution as entropy. Toward a unified theory of biology. University of Chicago Press, Chicago, $415 \mathrm{p}$.

BURT, D. R. R. 1976. On two new tetrabothriid cestodes from the brown gannet or booby Sula leucogastra plotus (Forster) from the Indian Ocean. Zoological Journal of the Linnean Society 58: 309319.

- 1978. On the cestode Tetrabothrius sulae Szpotanska 1929 from the brown booby or gannet Sula leucogastra plotus (Forster, 1844) of the Indian Ocean. Zoological Journal of the Linnean Society 64: $9-14$.

FARRIS, J. S. 1970. Methods for computing Wagner trees. Systematic Zoology 19: 83-92.
Fink, W. L. 1982. The conceptual relationship between ontogeny and phylogeny. Paleobiology 8: 254-264.

FunRmanN, O. 1932. Les ténias des oiseaux. Mémoires de L'Université de Neuchâtel 8: 1-383.

GaLKIN, A. K. 1987. O stanovlenii netsiklofillidnykh tsestod parazitov chaek. Trudy Zoologicheskogo Instituta AN SSSR (Leningrad) 161: 3-23.

GLeN, D. R., AND D. R. Brooks. 1985. Phylogenetic relationships of some strongylate nematodes of primates. Proceedings of the Helminthological Society of Washington 52: 227-236.

HenNig, W. 1966. Phylogenetic systematics. University of Illinois Press, Urbana, 263 p.

HOBERG, E. P. 1986. Evolution and historical biogeography of a parasite-host assemblage: $\mathrm{Alca}$ taenia spp. (Cyclophyllidea: Dilepididae) in Alcidae (Charadriiformes). Canadian Journal of Zoology 64: 2576-2589.

2. 1987a. Recognition of larvae of the Tetrabothriidae (Eucestoda): Implications for the origin of tapeworms in marine homeotherms. Canadian Journal of Zoology 65: 997-1000.

- _ 1987b. Tetrabothrius shinni sp. nov. (Eucestoda) from Phalacrocorax atriceps bransfieldensis (Pelecaniformes) in Antarctica with comments on morphological variation, host-parasite biogeography, and evolution. Canadian Journal of Zoology 65: 2969-2975.

LiNTON, E. 1922. A contribution to the anatomy of Dinobothrium, a genus of selachian tapeworms; with descriptions of two new species. Proceedings of the United States National Museum 60: 1-9.

LUNDBERG, J. G. 1972. Wagner networks and ancestors. Systematic Zoology 21: 398-413.

Murav'Eva, S. I. 1975. Morfologo-anatomicheskie osnovy sistematiki tetrabotriid. Problemy Parazitologii 2: 49.

— AND V. N. Popov. 1976. Sistematicheskoe polozhenie i nekotorye dannye ob ekologii Anophryocephalus skrjabini (Cestoda: Tetrabothriidae) - parazita lastonogikh. Zoologicheskie Zhurnal 55: $1247-1250$.

NyBELIN, O. 1916. Neue Tetrabothriiden aus Vögeln. Zoologischen Anzeiger 47: 297-301.

. 1922. Anatomisch-systematische Studien über Pseudophyllidean. Göteborgs Kunglia Vetenskaps och Vitterhets-Samhälles Handlingar 26: 169-211.

ODENING, K. 1982. Cestoden aus Flugvögeln der Südshetlands (Antarktis) und der Falklandinseln (Malwinen). Angewandte Parasitologie 23: 202223.

Rawson, D. 1964. Sequences in the maturation of the genitalia in Tetrabothrius erostris (Loennberg, 1889) from the intestine of Larus argentatus Pontoppidan. Parasitology 54: 453-465.

ReEs, G. 1956. The scolex of Tetrabothrius affinis (Lönnberg), a cestode from Balaenoptera musculus L., the blue whale. Parasitology 46: 425-442.

SCHMIDT, G. D. 1986. Handbook of tapeworm identification. CRC Press, Boca Raton, Florida, 675 p.

Skrjabin, A. S., and S. I. Murav'eva. 1972. Pervoe obnaruzhenie tsestod Tetrabothrius curilensis (Tetraphyllidea) u kashalotov (Physeter catadon 
L.) dobytykh v vodokh antarktiki. Vestnik Zoologii 1972(6): 85-87.

, AND -. 1978. Nekotorye itogi izucheniia tetrabotriid (Cestoda, Tetrabothriidae) parazitov krupnikh promyslovykh kitov iuzhnogo polushariia. Vestnik Zoologii 1978(3): 53-59.

SPASSKII, A. A. 1958. Kratkii analiz sistemy tsestod. Ceskoslovenska Parasitologi 5: 163-171.

SpÄтLICH, W. 1909. Untersuchungen über Tetrabothrien. Ein Beitrag Zur Kenntnis des Cestodenkorpers. Zoologische Jahrbücher Abteilung für Anatomie und Ontogenie der Tiere 28: 539-594.

SwOFFoRD, D. L. 1985. Phylogenetic analysis using parsimony. Version 2.4. Published by the author, Champaign, Illinois.

Temirova, S. I., AND A. S. SkrJabin. 1978. Tetrabotriaty $\mathrm{i}$ mezotsestoidaty lentochnye gel'minty ptits i mlekopitaiushchikh. Osnovy Tsestodologii
9. Akademiia Nauk SSSR, Izdatel'stvo Nauka, Moskva.

WARDle, R. A., AND J. A. McLeod. 1952. Zoology of tapeworms. University of Minnesota Press, Minneapolis, $780 \mathrm{p}$.

Watrous, L. E., AND Q. D. Wheeler. 1981. The outgroup comparison method of character analysis. Systematic Zoology 30: 1-11.

WileY, E. O. 1981. Phylogenetics. The theory and practice of phylogenetic systematics. John Wiley and Sons, Inc., New York, 439 p.

Williams, H. H. 1968. The taxonomy, ecology and host-specificity of some Phyllobothriidae (Cestoda: Tetraphyllidea), a critical revision of Phyllobothrium Beneden, 1849 and comments on some allied genera. Philosophical Transactions of the Royal Society, Series B 253: 231-307. 